\title{
Plankton of Southern Chilean fjords: trends and linkages*
}

\author{
TARSICIO ANTEZANA \\ Departamento de Oceanografía, Universidad de Concepción, Concepción, Chile. E-mail: antezana@udec.cl
}

\begin{abstract}
SUMMARY: The present paper compiles and reviews past and recent results from Magellan and Fuegian fjords for an overview of the planktonic assemblage there. It first examines linkages to local, adjacent and remote environments. The plankton assemblage presents deviations from the biota of the Magellan biogeographic Province, where the occasional presence of Antarctic species is related to oceanographic phenomena at the Polar Front. Complex bathymetric and hydrographic features within the fjords suggest that the plankton is rather isolated. Adaptations and constraints for population survival, and the role of diel migrators and gregarious zooplankters with regard to bentho-pelagic coupling are discussed. Results on seasonal differences in the plankton of the largest and most isolated basin of the Strait of Magellan are compiled. In spring the plankton was dominated by large diatoms suggesting a short food chain where most of the phytoplankton bloom goes to the bottom, to the meroplankton and to a few dominant holoplankters. In summer, the phytoplankton was dominated by picoand nanophytoplankton suggesting a more complex food web mediated by a bacterial loop. High abundance of holo- and meroplanktonic larvae coincided with spring blooming conditions.
\end{abstract}

Key words: Estuarine, Subantarctic, adaptations, patterns, seasonal, migration, food webs.

RESUMEN: PLANCTON DE LOS FIORDOS DEL SUR DE CHILE: TENDENCIAS Y CONEXIONES. - Este trabajo compila y revisa los resultados pasados y recientes de los fiordos fueguinos y magallánicos para proporcionar una visión integral de la comunidad planctónica. Primero se examinan las conexiones con los ambientes locales adyacentes y remotos. La comunidad planctónica presenta desviaciones de la biota de la Provincia biogeográfica Magallánica, donde la presencia ocasional de especies antárticas se relaciona con fenómenos oceanográficos en el Frente Polar. Rasgos batimétricos e hidrográficos complejos en los fiordos sugieren que el plancton está más bien aislado. Se discuten las adaptaciones y limitaciones para la supervivencia poblacional y el papel de los migradores diarios y del zooplancton gregario con respecto al acoplamiento bentopelágico. Se resumen los resultados sobre diferencias estacionales en el plancton de la más vasta y aislada cuenca del Estrecho de Magallanes. En primavera, el plancton estuvo dominado por diatomeas grandes, sugiriendo una cadena trófica corta, en la que la mayor parte de la biomasa producida va al fondo, al meroplancton y a unos pocos organismos dominantes del holoplancton. En verano, el fitoplancton estuvo dominado por pico- y nanofitoplancton, sugiriendo una red trófica más compleja mediada por un bucle bacteriano. La gran abundancia de larvas holo- y meroplanctónicas coincidió con las condiciones de proliferación primaveral.

Palabras clave: Estuario, subantártico, adaptaciones, patrones, estacional, migración, redes tróficas.

\section{INTRODUCTION}

Located north of the Polar Front and closer to the Antarctic than any other large land mass, the Magellan and Fuegian fjords are directly linked to the

\footnotetext{
*Accepted December 23, 1998
}

West Wind Drift and by extension to the Antarctic ecosystem. Plankton organisms which by definition drift with the current, may enter this archipelagic system to encounter a significantly different and heterogeneous environment and will respond to this new environment in highly variable ways according to their specific adaptive abilities. Some organisms 
may not drift passively with the current and be able to control their horizontal transport and remain in specific locations (Kaartvedt, 1993). Therefore, the structure of the community within the fjords is expected to be significantly different from the open ocean, as individual species, rather than species assemblages, respond to environmental forces (McKelvie, 1985). Differences between basins are expected in this physically complex environment where bathymetry and water characteristics differ in short distances and time periods (Pickard, 1971; Panella et al., 1991; Antezana et al., 1992; Antezana, 1999).

Plankton linkages to remote or adjacent systems and trends in community structure will basically vary according to the scale of physical driving forces and biological processes involved. These factors and their effect on the plankton are poorly known in this archipelagic system. The present paper will attempt to compile and review recent results from the Magellan and Fuegian fjords for an overview of planktonic communities.

\section{LINKAGES IN A SPATIAL GRADIENT}

The term "linkage" is used here to express a simple connection between assemblages through different interphases or habitats. "Link" is used in the same context as "linkage" but in a more specific or particular sense. "Coupling" instead implies in the context of this review, a conceptually well defined dynamic interaction (e.g. energy flow process).
Linkages associated to the Magellan and Fuegian pelagic environments are multivariate in space (and in time) but could be summarized step wise according to direct or immediate connections (Fig. 1). From a small to a large scale, the pelagic environment is connected to adjacent interphases of a single basin and this one to other basins, which together form the archipelagic system, connected as such to the Pacific and Atlantic ocean and these to the Antarctic ocean. Therefore a linkage between the largest and the smallest habitat is indirect and likely mediated by long-term processes. Instead, linkages between proximate adjacent habitats (e.g. between the mixed layer and the bottom layer) are likely associated to comparatively shorter time scale. For instance, while immigration and colonization of the fjords by Antarctic or Subantarctic species may be achieved in the scale of decades to centuries, pulses of sedimentation of spring phytoplankton blooms may occur in the scale of hours to weeks. Basin to basin interactions are likely to be of intermediate time scale (e.g. nutrient or population import-export may be seasonal to annual). Genetic divergence of Antarctic species (Euphausia superba Dana 1852, Euphausia crystallorophias Holt and Tattersall 1906) from the Subantarctic species Euphausia vallentini Stebbing 1900 was estimated at ca. 20 million years, which is consistent with the formation of a circum-Antarctic water circulation and the Antarctic Polar Front (Patarnello et al., 1996).

At the biogeographic scale, the study area lies within the geographical range of the so-called Antiboreal South America (Eckman, 1953), Magellan

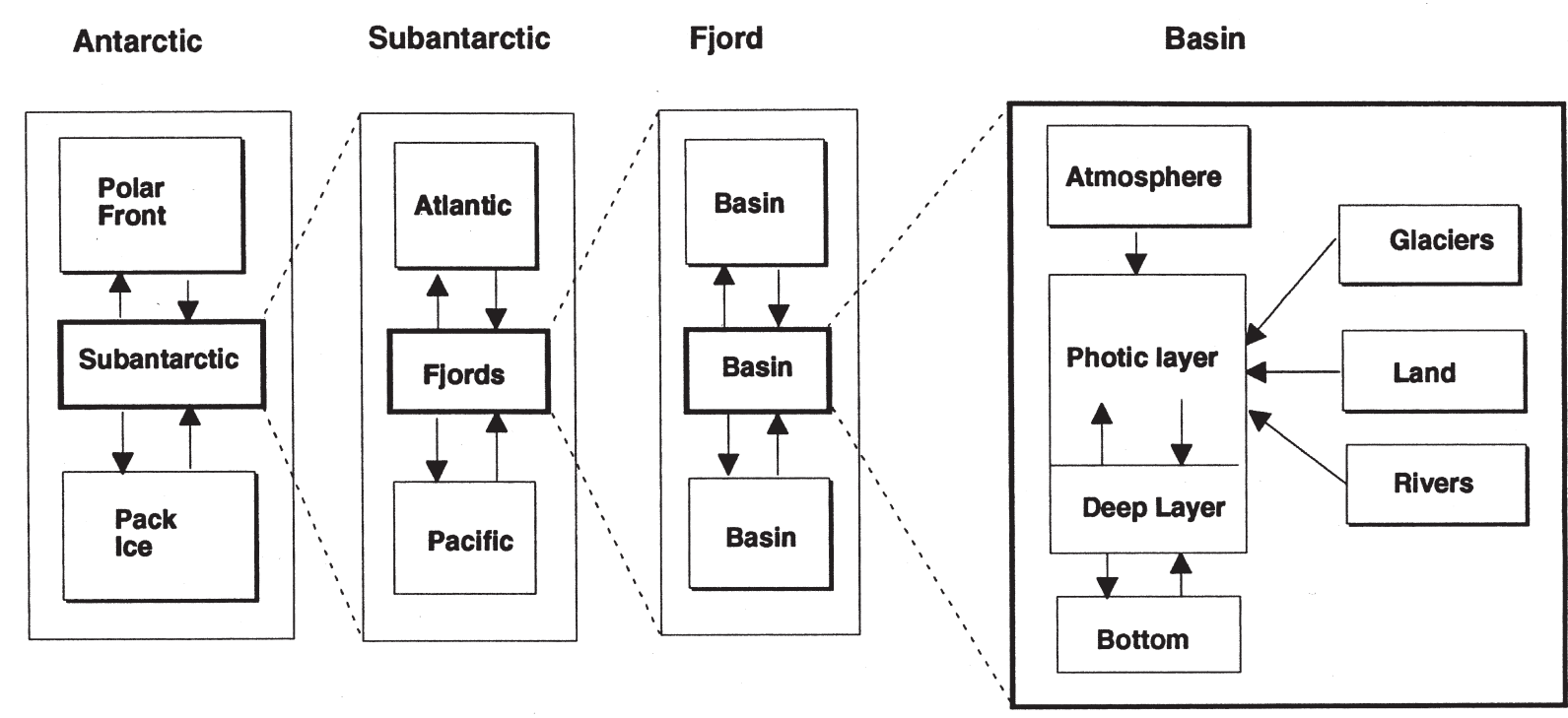

FIG. 1. - Linkages of the plankton assemblage of southern Chilean fjords: a conceptual model of progressively larger scales of interactions between the Antarctic and a single basin. 
(Balech, 1954; Schilder, 1956; Briggs, 1974) or Magellanean Province (Antezana, 1981). The biota of the fjords have components of this province such as Subantarctic copepods (Marín and Antezana, 1985; Mazzocchi and Ianora, 1991), euphausiids (Antezana, 1976) and other zooplankters (Guglielmo et al., 1991; Antezana et al., 1992), but they also have components such as euphausiids (Antezana, 1976) belonging to the Transition Zone (sensu Brinton, 1962).

Although the Antarctic biota are to a large extent endemic to the Antarctic system (Ekman, 1953; Mackintosh, 1934), several planktonic species extend their distribution to Subantarctic waters approaching the southern tip of South America and enter archipelagic waters (Table 1). Among them, several species of copepods (Marín and Antezana, 1985; Mazzocchi and Ianora, 1991), euphausiids (Antezana, 1976; Guglielmo et al., 1997), chaetognaths (Alvariño et al., 1983), siphonophores (Alvar-

TABLE 1. - Antarctic zooplankters extending their distribution beyond the Polar Front.

Taxa South Eastern Pacific Chilean Archipelago

\section{Siphonophora}

After Alvariño et al. (1990)

Dyphies antartica

Scyphomedusae

After Larson (1986)

Atolla chunni

Desmonema cornatum

present

present

present

present

present

Chaetognatha

After Alvariño et al. (1983), Ghirardelli et al. (1991)

Eukronhia hamata

Eukronhia bathyantartica

Sagitta marri

Sagitta gazellae

Sagitta planctonis

common
rare
rare
common
common

common

rare

rare

common

common

Copepoda

After Marín and Antezana (1985), Mazzocchi and Ianora (1991)

$\begin{array}{cc}\text { common } & \\ \text { common } & \text { common } \\ & \text { rare } \\ \text { rare } & \text { rare } \\ \text { common } & \text { rare } \\ \text { common } & \text { rare } \\ \text { common } & \text { rare } \\ \text { common } & \text { common }\end{array}$

Euphausiacea

After Antezana et al. (1976), Antezana (1978, 1981),

Guglielmo et al. (1991)

common

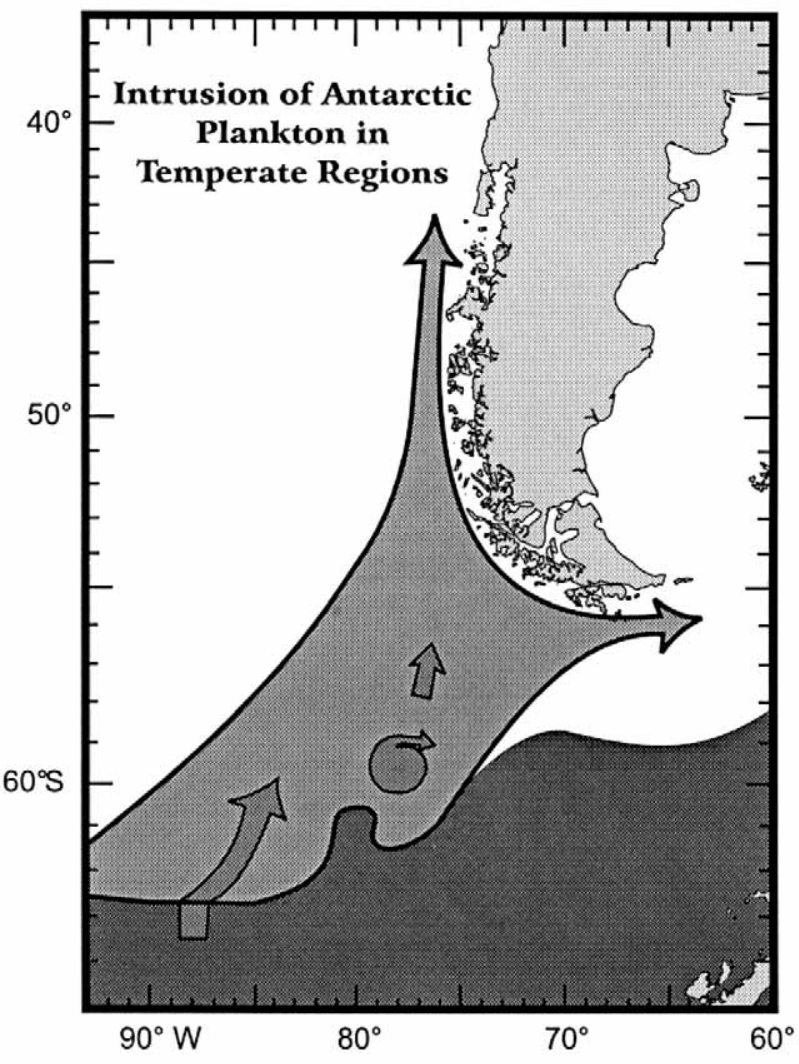

FIG. 2. - Intrusion of Antarctic species into subpolar and temperate regions of the South Eastern Pacific: a conceptual model including the formation of cold rings, Antarctic Intermediate water mass and surface water beyond the Polar Front.

iño et al., 1990) and medusae (Larson, 1986) have been found in the southern fjords. Most of these species are surface dwellers of the Antarctic ocean, but others such as Eukrohnia hamata (Möbius 1875) and Spinocalanus terranovae (Damkaer, 1975) are deep living species.

Several mechanisms may explain the intrusion of Antarctic planktonic species in more temperate regions including the Chilean fjords (Fig. 2). At the Polar Front, dense surface Antarctic waters subside below lighter Subantarctic waters forming the Antarctic Intermediate water mass which has a northward component extending beyond the equator (Deacon, 1937). Surface living species in the Antarctic occur commonly in deep waters across the south and north Pacific and are occasionally found in surface waters (David, 1958; Alvarino, 1965). Alternatively, as happens in other frontal systems (Wiebe et al., 1976), the Polar Front, while meandering across the Pacific near South America, may form cold rings which transport endemic Antarctic plankton communities into warmer regions as they fade away in the course of several months. Further- 


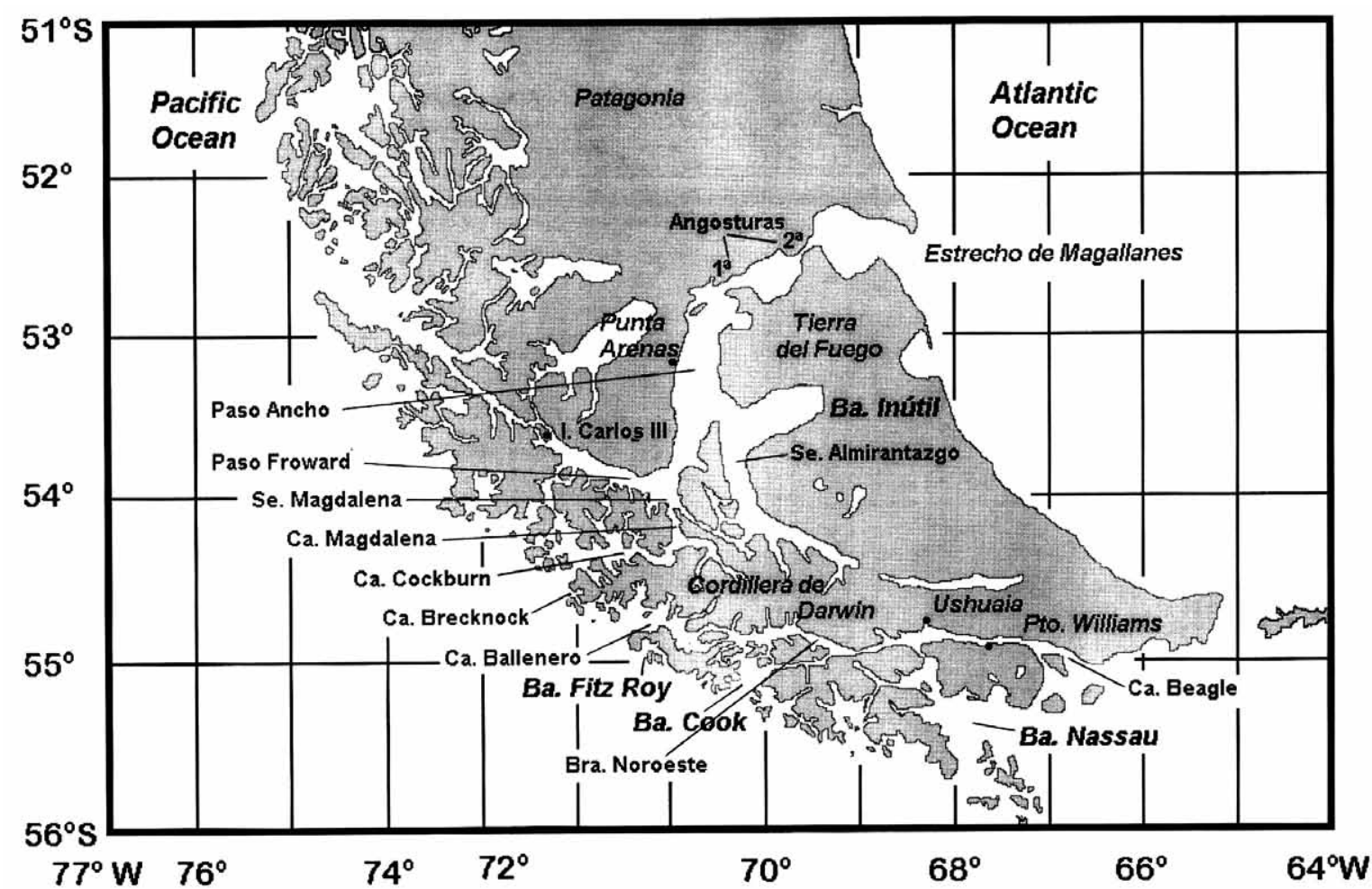

FIG. 3. - Main passages within the Magellan and Fuegian fjord region and its oceanic connections.

more, the Polar Front itself is the core habitat for some species such as Euphausia triancantha Holt and Tattersall 1906, which decreases in numbers northward and southward (Baker, 1959). The common occurrence of juveniles of E. triacantha in the open Pacific Ocean up to $48^{\circ} \mathrm{S}$ (Antezana, 1978) and in the fjords (Guglielmo et al., 1991; Antezana et al., 1992) and of species of siphonophores (Alvariño et al., 1990) may be explained by a continuous northward advection of surface waters at the Polar Front.

Such mechanisms could also explain the occurrence of Euchaeta antarctica (Giesbrecht 1902), Clausocalanus laticeps (Farran 1929), Candacia cheirura Cleve 1904 (see Marín and Antezana, 1985) and of swarming juveniles of E. superba in some deep basins near the open Pacific Ocean at $48^{\circ} \mathrm{S}$ (Antezana and Aguirre, 1976), as may be the case for other Antarctic plankters found in the Straits of Magellan and along the Chilean fjord region.

On a smaller spatial scale, linkages of plankton of Magellan and Fuegian fjords with open Atlantic and Pacific waters (Fig. 3) were examined through the study of bathymetry and hydrography. The influence of Pacific Subantarctic waters in the Straits of Magellan extends to Isla Carlos III located half way from the western Pacific entrance, where an abrupt rise of the bottom and an extreme narrowing of the basin prevents the eastward inflow of waters. The influence of Subantarctic Atlantic waters into the Straits of Magellan reaches the Angosturas on the eastern Atlantic entrance, where bottom depth, considerably shallower than Paso Ancho and the horizontal contraction of the basin, likely restricts the inflow of Atlantic Subantarctic waters (Antezana et al., 1992). Temperature, salinity and density profiles along the Straits of Magellan (Pickard, 1971; Artegiani and Paschini, 1991; Panella et al., 1991) support these conclusions. From the faunistic point of view, the sill on the Pacific entrance and the shallow Angosturas extending to the Atlantic shelf seem firm barriers for the penetration and distribution of oceanic plankton into the Straits of Magellan (Antezana et al., 1992), as has been demonstrated for copepods (Mazzocchi and Ianora, 1991), phytoplankton (Uribe, 1991; Cabrini and Fonda Umani, 1991; Marino et al., 1991) and chlorophyll (Panella et al., 1991; Saggiomo et al., 1994; Carrada et al., 1994). A degree of variability to these limits was found in microzooplankton indicating that the Atlantic entrance basin extends only to Bahía Inútil and the Pacific entrance basin reaches Cabo Froward (Fonda Umani and Monti, 1991). 
Additional intrusion of open ocean waters into the Strait of Magellan likely occurs through southern Magellan and Fuegian fjords and is also restricted by bottom topography and horizontal narrowing of channels according to Antezana (1999). This author mentioned that although the Fuegian channels are connected to the Pacific through several passages at Bahía Cook, Bahía Fitz Roy, Bahía Nassau and others, the presence of sills 20-50 m deep, added to lateral contractions of the basins at or near the entrance, likely restricts the intrusion of subsurface waters and associated plankton into the archipelagic system. Nevertheless the intrusion of Pacific waters into deep inland basins ( $c a .400-600 \mathrm{~m}$ ) was detected in subsurface warm and saline waters of Subantarctic characteristics located along Canal Ballenero and Brazo Noroeste in the glacier sector of Canal Beagle. This subsurface water mass may extend through Canal Cockburn and Canal Magdalena toward Seno Magdalena and Paso Ancho, while mixing with upper brackish waters (collected through several inlets north and west of Cordillera de Darwin) takes place. Thus, intrusion of waters from the open ocean into the Fuegian fjords as well as into the Magellan fjords is likely episodic and rather constrained by bathymetry and topography, therefore water and plankton exchange with the open ocean is reduced, whereas exchange between basins seems comparatively of much greater importance (Antezana, 1999).

Linkages of the plankton assemblages between basins are likely determined by bottom and horizontal topography too, resulting in plankton assemblages with distinctive species composition and abundance and associated with water properties, bottom depth and substrate type. For instance, cold or deep living oceanic species occurred in a cold and deep Norwegian fjord, whereas migratory suprabenthic animals characterized the water column of another nearby fjord (Richard and Haedrich, 1991). Elsewhere, abrupt changes in bottom topography associated with seamounts, slope and shelf may affect the distribution of zooplankton to such an extent that zooplankton is accumulated in shallower areas or probably stranded near the bottom (Isaacs and Schwartzlose, 1965; Hobson and Chess, 1986; Simmard et al., 1986). Plankton was also excluded from shallow areas and varied its diel migratory behaviour (Genin et al., 1988). Changes of the diel migratory pattern prevented nocturnal transport of euphausiids into the shallow, innermost shelf of the fjord where vulnerability to visual predators increased (Kaartvedt, 1993). Thus, bottom depth may determine differences in the species composition of plankton between nearby inlets and current tidal regime may cause complex pattern of retention, dispersal and exchange of plankton species between fjords. Both tidal currents and bottom depth are likely important factors determining basin to basin linkages.

At the scale of a single basin, linkages may be defined with respect to immediate interphases (air/water, land/water and water/bottom), and could be depicted in a conceptual model representing energy or material flow between compartments (Fig 4). The objective of such an approach was to examine trends in the plankton assemblage at several scales. Such compartment models have been widely suggested for coastal and open ocean waters (Beers, 1986; Jumars, 1993) and also for fjords systems (Hopkins et al., 1989). In this study its serves as a framework to identify the most relevant compartments and their interactions in this region, and to bring together recent scattered results. This diagram includes the basic compartments of most trophic webs namely producers, consumers, Particulate and Dissolved Organic Matter (POM and DOM), and stresses locally relevant features. Among them: 1.two types of food webs within the system (classic and bacterial loop food webs) for spring and late summer - winter, 2.- size fractions within the producer compartment and a few taxa among the zooplankton consumers, 3.- material flow between the water column and the bottom in both directions. Such a model, far from being complete and fully sounded, is of heuristic value.

Although plankton linkages to air, walls, glaciers and particularly to subtidal habitats are important in narrow fjords (Syvitski et al., 1987), in the context of this work it is most pertinent to examine just some pelagic-benthic links within a given basin.

Bentho-pelagic coupling is particularly important in this region. Evidence indicates a strong link between phytoplankton production, vertical diel migration of zooplankters and the benthic environment. Blooming conditions characterized by high concentrations of chlorophyll were detected in Paso Ancho in spring 1989 (Panella et al., 1991) and in Paso Ancho and several Magellan and Fuegian basins during the "Victor Hensen" cruise in spring 1994 (Antezana and Hamamé, 1999; Hamamé and Antezana, 1999). Blooming conditions during this cruise were characterized by predominance of chain forming diatoms (Antezana et al., 1996). In late 


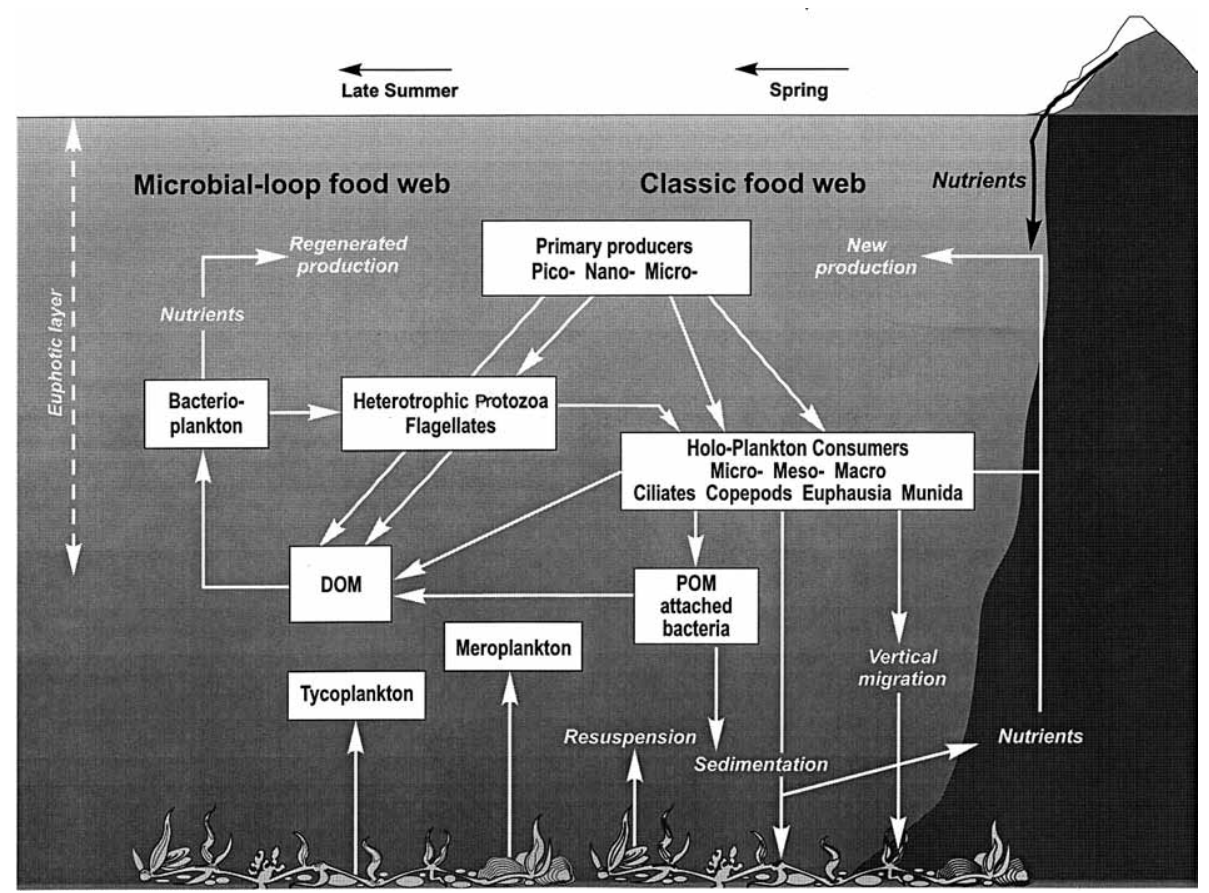

FIG. 4. - Hypothetical food web within a fjord, including alternative spring and summer flow patterns of organic matter. Only major categories and links are included for simplicity.

summer, chlorophyll concentrations were much lower (Carrada et al., 1994; Saggiomo et al., 1994) but primary production was as high as $1 \mathrm{gCm}^{-2} \mathrm{~d}^{-1}$ in some basins (Magazzu et al., 1991; Saggiomo et al., 1994). Furthermore, spring and summer blooms of dinoflagellates frequently developed into extended and intensive red tides in the region (Campodónico et al., 1975; Guzmán et al., 1975; Uribe, 1988).

It is likely that most of these blooms are hardly utilized by holozooplankton grazers in the water column but reach the bottom, particularly in shallow areas (Syvitski et al., 1987). Two conditions appeared to favour this vertical transport. In Paso Ancho the water column is fully mixed, therefore the effect of vertical retention by the pycnocline is likely diminished. Instead, the water column was strongly stratified by the presence of a 0-30 m core of brackish water, in the glacier sector of Brazo Noroeste, below which occurred the chlorophyll maximum (Hamamé and Antezana, 1999). Since this subsurface core was not affected by wind mixing, and the depth of the basin was less than $300 \mathrm{~m}$, sinking of phytoplankton to the bottom was likely. Furthermore, the low density of grazers (copepods and euphausiids at least) near the glacier sector of Brazo Noroeste as compared to Paso Ancho (Antezana et al., 1996; Hamamé and Antezana, 1999) suggests that the phytoplankton bloom could reach the bottom with minimum or no utilization in the water column. A second line of evidence supporting this idea was obtained from sediment samples with bottom piston cores. A thick greenish mat or "fluffy" deposited organic matter was frequently observed through the study area covering the bottom (Gutt and Schickan, 1996). Unpublished data of phytoplankton pigment concentrations of the upper $5 \mathrm{~mm}$ of this mat were as high as $25.4 \mathrm{mg}$ chlorophyll eq. $\mathrm{m}^{-2}$ on average $(\mathrm{SD}=17)$. Similar layers of chlorophyll could be buried to a depth of $2 \mathrm{~cm}$, in a shallow Scottish fjordic sea-loch, less than 10 days after the bloom had settled (Overnell et al., 1995).

This bulk input of organic matter to the bottom should enhance benthic production, spawning, larval recruitment and other reproduction related processes of benthic invertebrates which can be triggered by the onset of or during spring blooms. Larval release of the snow crab Chionoecetes opilio in a subpolar fjord was associated with the sedimentation peak of phytoplankton particles from a surface spring bloom. Further experiments induced larval release with senescent cultures of phytoplankton species (Starr et al., 1994 ). Consistent with this idea, a large proportion of larvae of benthic invertebrates was found in samples collected in the glacier sector of Brazo Noroeste of Canal Beagle, where highest densities of chlorophyll were encountered. The massive occurrence of larvae during spring phytoplankton conditions was not restricted to benthic 
invertebrates but encompassed planktonic animals as indicated by high densities of larval stages of copepods and euphausiids (Antezana et al., 1996; Hamamé and Antezana, 1999).

Vertical diel migration and the transport of organic matter is another example of bentho-pelagic coupling. Classically, organisms actively feeding in the euphotic layer during dark hours migrate to subphotic layers where they decrease the probability of being eaten by visual predators. E. vallentini is the most abundant euphausiid of the Chilean fjords where it is often found in dense swarms (Antezana, 1976). It was a dominant species of the zooplankton in the Straits of Magellan, particularly in Paso Ancho, where it performed strong vertical migrations between the upper $50 \mathrm{~m}$ and the stratum immediately overlying the bottom (Guglielmo et al., 1997). It is likely, as suggested by González (1992) for the Antarctic, that sinking faeces of E.vallentini produced in the upper layer of these fjords will constitute a substantial, patchy source of organic matter to the benthos. Additionally, downward migrating herbivores may reach close proximity to the bottom substrate and provide a rich, seasonally predictable food source to benthic invertebrates (Dearborn et $a l ., 1986)$. The occurrence of planktonic diel migrators in shallow waters presents some interesting possibilities with respect to their ability to make use of alternative food sources during their proximity to hard substrate. Some euphausiid species are known to stir the bottom and feed on re-suspended organic material (Mauchline and Fischer, 1969), others to scrape the ice (Hamner et al., 1983), so the presence of detritus covering the sediments could be a suitable alternative food source also for E. vallentini during their day time descent, particularly when surface chlorophyll is low.

Pelagic crustaceans such as Nauticaris marionis Bate, 1888 are important components of the benthopelagic coupling in other shallow Subantarctic areas where phytoplankton blooms are hardly utilized by holoplankton grazers. Whereas adults are found near the bottom and feed upon benthic suspension feeders, megalope larvae utilize the phytoplankton in the surface layer during the night hours of their diel migration (Perissinotto et al., 1990).

One may also expect a similar role in benthopelagic coupling for Munida gregaria (Fabricius 1793) and Munida subrugosa (White 1847) in the Chilean fjords, where both species are abundant and frequent. M. gregaria is a pelagic dweller forming large and dense aggregations in the upper layer of the southern Chilean fjords (Tabeta and Kanamaru, 1970; Antezana, 1976; Kawamura, 1976), and M. subrugosa was the most common decapod during the "Victor Hensen" cruise (Gorny et al., 1996) .

Bentho-pelagic coupling also occurs in the opposite direction, from the benthal to the pelagial, as indicated by the presence of benthic diatoms in the water column in the Angosturas basin at the eastern Atlantic entrance of the Straits of Magellan (Uribe, 1991), and by the frequent encounter of benthic living animals (e.g., amphipods and polychaetes) in zooplankton samples collected at night (Antezana et al., 1996; Hamamé and Antezana, 1999). Similar results were obtained by Richard and Haedrich (1991) in a shallow Newfoundland fjord, where nine out of the eleven species of the pelagial of this fjord were gammarids, amphipods, mysids or semi-demersal shrimps, all suprabenthic species normally found in association with the substrate.

\section{ENVIRONMENTAL CONSTRAINTS ON ZOOPLANKTON POPULATIONS}

The oceanic zooplankton which is advected into the fjords encounters an environment which is very different from its presumed open ocean home area. After passing the shallow sills at the mouth of inland passages zooplankters are likely trapped within the system (Antezana, 1999), and become expatriates or vagrants (sensu Sinclair, 1988), as must be the case for Subantarctic and Antarctic species found in the Magellan and Fuegian fjords. Here they find a uniquely heterogenous environment driven by fresh water input from land, rivers and glaciers, mixing with salt water in a complex interaction of tidal currents, wind stress, internal friction and bottom friction. One would anticipate that many organisms do not survive these sudden chemical, temperature and other physical stresses and perish. In fact species richness for copepods was greatest at the Pacific entrance of the Straits of Magellan due to the presence of a number of typically Antarctic species and other dwellers of subsurface or deep slope oceanic waters. Species richness abruptly diminished in the intermediate basin (Mazzocchi and Ianora, 1991).

Those individuals which do survive within this environment encounter dominant physical forces which differ considerably from those in the open ocean. The most notable among these are strong horizontal advection and variable bottom depth. 
Advective forces may drastically affect dispersion and retention of population members, and variable bottom depth may equally alter the behaviour of some species (e.g., circadian migration) .

Two alternative responses may be envisioned with respect to horizontal advection. Individual plankters are either dispersed by small scale forces and become separated from their population (Huntley and Niiler, 1995) or they are able to maintain the coherence of the population by a combination of both behaviour and the physical forces of fluid dynamics. For a long-lived holoplankter such as $E$. superba, Huntley and Niiler (op.cit.) suggested that by the time individual members of an identifiable population reach maturity, they will have dispersed to such a degree that they are no longer recognizable as a single population sensu Sinclair. Within the fjords, tidal currents and changes in depth and width of the inlet passages may generate much stronger dispersive forces. In fact, surface velocity from navigational charts is considerably greater than in the open ocean.

On a large scale it could be reasonably assumed that the exchange of water with the open ocean is more restricted by the presence of sills than water exchange between large basins of continuous bottom profile (Antezana, 1999); therefore the encounter probability and interbreeding with other members of the population increases.

On a small scale, an enhanced capacity to swim and compensate for net horizontal water movement and the social drive to form dense aggregations may give special advantage to large pelagic animals over smaller ones. Evidence suggesting that these mechanisms may be effective for large pelagic animals in these passages are: the frequent encounter of swarms of $E$. vallentini and other zooplankters throughout the region (Antezana, 1976) and particularly in the Straits of Magellan (Guglielmo et al., 1997) and the encounter of discrete and large surface aggregations of $M$. gregaria, which maintain their shape despite local currents (Tabeta and Kanamaru, 1970; Kawamura, 1976).

Another mechanism that may cause organisms to remain in specific and predictable locations is related to changes in the diel pattern of vertical migration. In some instances organisms may avoid the upper layer where major horizontal advection occurs (Kaartvedt, 1993).

A major exclusive force for many oceanic species encountered in the fjord environment is the effect of variable bottom topography on vertical diel migration. In shallower areas plankters can be accumulated, trapped or stranded at the bottom. Such phenomena reported for coastal shelves and banks (Isaacs and Schwartzlose, 1965; Simmard et al., 1986; Hobson and Chess, 1986; Genin et al., 1988) result in increased vulnerability to predators.

E. vallentini, a dominant holoplankter in the area can occur near the bottom of basins like Paso Ancho. Horizontal stratified samples were taken there on a discrete aggregation of $E$. vallentini at less than $2 \mathrm{~m}$ from the bottom in the day and in the upper $20 \mathrm{~m}$ at night (Guglielmo et al., 1996). Species may compensate increased vulnerability to benthic and demersal predators by finding near the bottom either alternative food sources or refuge from pelagic predators. Upon entering the fjord environment, this Subantarctic species like other euphausiids and holoplankters, apparently finds habitats with suitable food conditions, attains maturity, reassembles with other members of the original open-ocean or local populations and eventually reproduces successfully, with the juveniles becoming members of a newly established population. Such may be the case for euphausiids according to observations obtained during this spring cruise. Adult females of E.vallentini with attached spermatophores, and egg-carrying females of Stylocheiron maximum Hansen,1908 were found; a specimen of the latter released eggs in vitro, which successfully developed into the early calyptopis stage in a period of days.

It is likely however, that individuals of restricted swimming capacity that cannot remain in a coherent group or in suitable areas will be separated or lost, and will become transitory or permanent vagrants within the fjord environment. In this case a local population defined as a "self-sustaining unit of a particular species" (Sinclair, 1988) may in fact function as a multiunit or metapopulation, sensu Pullian (1988). Días (1996) states that this concept which has displaced the niche concept among others, is particularly applicable to heterogeneous environments, where sink and source habitats may be identified after long term studies. Source habitats are characterized by the rise of a local demographic surplus whereas a local demographic deficit occurs in habitats of poor quality (sink habitat). Días claims that a permanent migration of propagules or individuals from source to sink habitats may lead to a stabilization of the overall demographic system. This concept may be very useful to explain and to evaluate large between-site differences in this fjord system. 
TRENDS AND ORDER IN THE PLANKTON ASSEMBLAGE

The environment of Magellan and Fuegian fjords presents several constraints to community organization such as selective immigration of open ocean species through shallow connections to inland passages, intrinsic complexity within the system caused by uneven input of fresh water and glacier effects, marked horizontal advective forces associated with strong tidal currents and a variable depth profile. This would be the result of individual species or size components of these species coping with those factors. Individual physiological adaptations to brackish waters and behavioural adjustments to dispersive or retention forces leading to successful survival, reproduction and settlement of individual populations may generate a chaotic structure in the community.

Yet, scattered and preliminary evidence indicates a certain degree of internal order and organization of the planktonic assemblage in the region, in a range of scales which include geographic distribution, seasonality of phytoplankton and animal behaviour.

"Trend" in this context refers to the tendency of a given variable or structure (e.g. phytoplankton biomass, food web) to change over a range of different spatial and temporal scales, even though it is often used to describe long-term changes.

A large scale expression of order in Magellan and Fuegian fjords is the occurrence of basins based on bathymetry profiles, hydrography and plankton distribution (Hamamé and Antezana, 1999). In the Straits of Magellan biotic assemblages have also been identified in the microzooplankton (Fonda Umani and Monti, 1991), meso and macrozooplankton (Guglielmo et al., 1991; Antezana et al., 1992; Mazzocchi et al., 1995) and among copepods (Mazzocchi and Ianora, 1991), phytoplankton species (Uribe, 1991; Cabrini and Fonda Umani, 1991) and their size fractions (Carrada et al., 1994; Saggiomo et al., 1994; Magazzu et al., 1996).

A seasonal trend was identified in the phytoplankton species composition, chlorophyll concentration and primary production for spring and summer in the Magellan and Fuegian passages. The seasonal succession in species dominance (Fig. 4 and 5) as documented by Cabrini and Fonda Umani (1991), Marino et al. (1991), Antezana et al. (1996) was characterized in spring by blooming conditions and the dominance of the chain forming diatoms Asterionella and Thalassiosira in 1989 and Thalassiosira and Chaetoceros in 1991 in Paso Ancho; and of
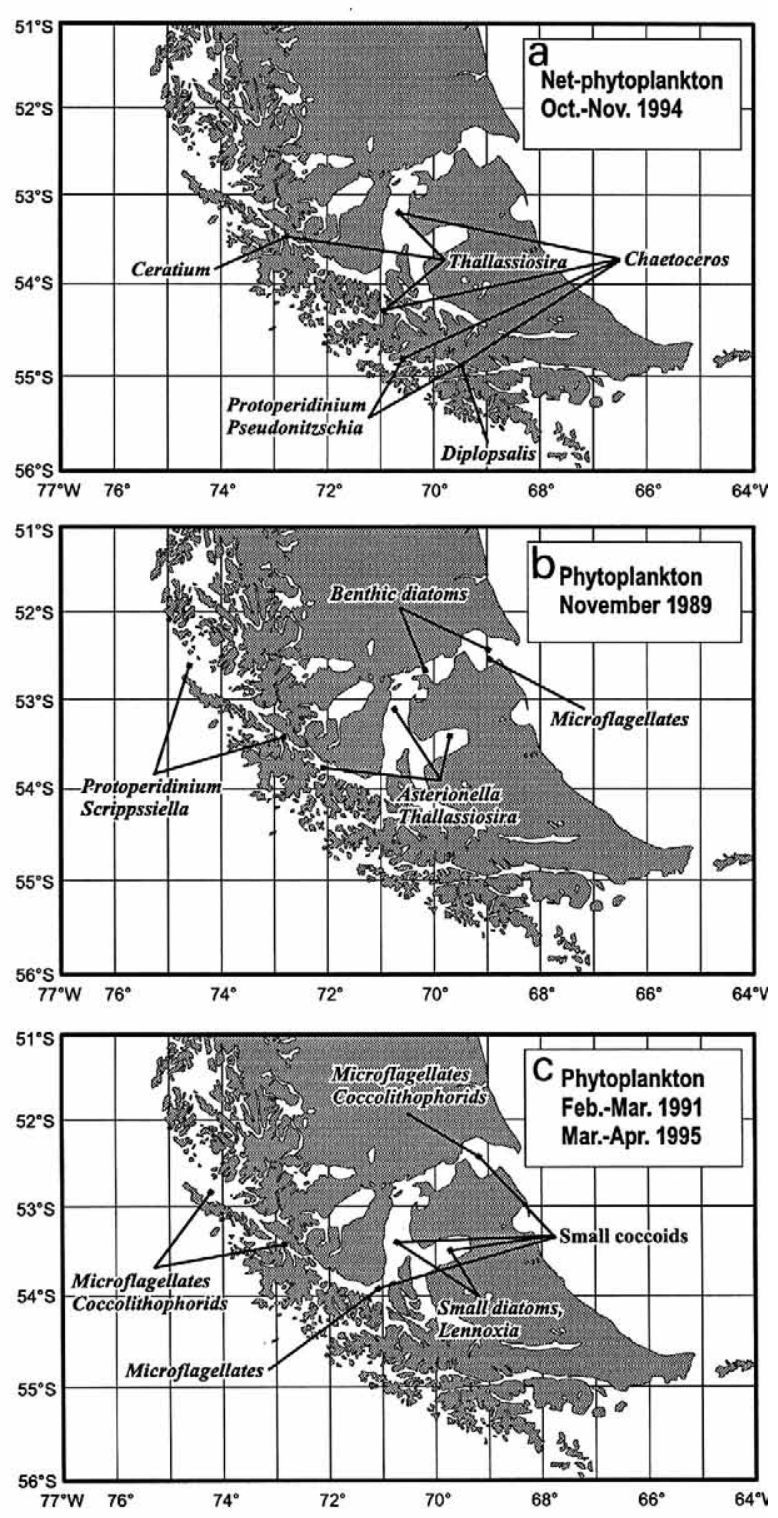

FIG. 5. - Dominant phytoplankton taxa during spring and summer along the Straits of Magellan and the Beagle Channel - Straits of Magellan passage. a.- October- November, 1994: after Antezana et al. (1996); b.- November, 1989: after Cabrini and Fonda Umani (1991); c.- February - March, 1991: after Marino et al. (1991).

dinoflagellates in the eastern Pacific entrance and of microflagellates and benthic diatoms in the shallow western Atlantic entrance of the Straits of Magellan. In spring 1994, Chaetoceros and Thalassiosira also dominated in Paso Ancho and extended to the Pacific entrance and to Canal Magdalena. Spring blooming conditions were also detected in the Fuegian fjords from Canal Ballenero to Canal Beagle with the dominance of the diatoms Chaetoceros and Pseudonitzschia and the dinoflagellate Diplopsalis.

The late summer phytoplankton assemblage differed considerably from spring phytoplankton. 
Small coccoid cells were found throughout the study area. Small diatoms dominated the Paso Ancho basin, and microflagellates and coccolitophorids dominated the Pacific and the Atlantic entrances of the Straits of Magellan.

Phytoplankton biomass showed a similar seasonal trend. Maximum values were found in spring and particularly in Paso Ancho in 1989 (Panella et al., 1991; Magazzu et al., 1996) and in Paso Ancho and in the glacier sector of Canal Beagle in 1994 (Antezana et al., 1996; Hamamé and Antezana, 1999). Phytoplankton biomass decreased in late summer in Paso Ancho, and was even more diminished at the Atlantic and Pacific entrances. Minimum chlorophyll concentrations occurred along the Straits of Magellan in early autumn (Magazzù et al., 1996). These authours showed a consistent seasonal pattern in the partitioning of biomass among size fractions during the onset and fall of the spring bloom. In spring 1989 , nearly $100 \%$ of the chlorophyll corresponded to net phytoplankton with a minimum contribution of $6 \%$ of the picoplankton $(<2$ $\mu \mathrm{m})$, which increased slightly at the Pacific and Atlantic entrances. In late summer and early autumn the contribution of picoplankton to the total chlorophyll content was ca. $60 \%$ throughout the area with slightly lower values at the Pacific and Atlantic entrances. In early autumn the contribution of picoplankton was ca. $50 \%$ of the other size fractions combined (op. cit.). This significant contribution of picoplankton and also microphytoplankton (2-10 $\mu \mathrm{m})$ to the total chlorophyll was also emphasized for the Chilean fjord region during late summer (Saggiomo et al., 1994; Carrada et al., 1994; Carrada et al., 1996) as well as their very low contribution during spring (Panella et al., 1991).

In northern high latitude fjords, early spring phytoplankton blooms are keyed to an irradiation threshold, sufficient water stratification and low grazing pressure (Syvitski, et al., 1987). Blooms probably end primarily because of nutrient depletion and are followed by increased input of exsudates from senescent phytoplankton cells to the dissolved organic matter (DOM) pool (Fuhrman, 1992), as well as to the particulate organic matter (POM) pool and subsequently to benthic detritivores (Wassmann et al., 1996). Phytoplankton production may continue at a reduced rate largely fueled by regenerated nutrients (Syvitski et al., 1987). In fact, ammonium uptake was the principal source of nitrogen during autumn of 1995 in the Straits of Magellan when regenerated production accounted for most of the primary production (Lipizer and Catalano, 1996). Heterotrophic production of bacteria has not been measured in southern Chilean fjords, however it is likely that an important loop of energy flow in post blooming conditions takes place here as in other subpolar fjords (Syvitski et al., 1987).

Seasonality in the phytoplankton community structure and production as indicative of internal organization is also apparent in zooplankton (Fig. 4). During the spring cruise of "Victor Hensen", plankton was dominated by larval stages of holoplankton and by meroplankton, which implies enhanced spawning associated to spring blooming conditions. The zooplankton assemblages at any particular station were commonly characterized by a few species forming dense discrete aggregations (Antezana, 1976). The dominance of some euphausiids (e.g. E. vallentini and other pelagic crustaceans such as $M$. gregaria) and their tendency to aggregate implies not only that these species are well adapted to this environment, but because of their dominance and patchy distribution in the pelagial, they may put a significant grazing pressure upon phytoplankton and other likely food sources. They could also significantly impact particulate organic matter in sediments through their large and rapidly sinking faeces (Wassmann et al., 1996). E. vallentini and M. gregaria have been mentioned in this context (Tabeta and Kanamaru, 1970; Antezana, 1976; Kawamura, 1976). Although a transient phenomenon and restricted to some species, aggregations of large zooplankton or micronektonic forms may drastically affect the distribution of phytoplankton and the course of phytoplankton blooms due to their localized grazing impact. Thus, de-coupling of phytoplankton and zooplankton resulting in blooming and sinking of phytoplankton to the bottom may be abruptly modified by pelagic aggregations by reducing the input of primary produced material to the bottom, and thereby increasing the flow of organic matter in the pelagic food web through nektonic predators or through a faeces mediated loop.

The role of E. vallentini and M. gregaria among other gregarious pelagic species within the fjord system may be comparable to that of their counterpart in the Antarctic ocean, the Antarctic krill E. super$b a$. Therefore special attention should be given to their presumed role in shaping the structure of the plankton assemblage and the dynamics of the bentho-pelagic coupling in this fjord region.

In conclusion, the plankton assemblage of the Magellan and Fuegian fjords is closely linked to the Subantarctic (and to a lesser extent to Antarctic) 
biota. In spite of the apparent complexity associated with various physical factors in the Magellan and Fuegian fjords, the plankton assemblage showed a degree of order in spatial or temporal trends on different scales. Microbasins were identified based on bathymetry, hydrography and species distribution. The main seasonal trend in the pelagial seems to be succession from a classical to a bacterial mediated food web. Linkages at a smaller scale, as depicted in a conceptual compartment model of a single fjord basin, stress the role of pelagic-benthic coupling through the behaviour of zooplankton migrators and blooming events.

\section{ACKNOWLEDGEMENTS}

This research was funded by the Alfred Wegener Institute and the University of Concepcion during the RV "Victor Hensen" cruise and JGOFS Chile SIDA-CONICYT project during succeeding stages. During the last stage of data processing and writing I was kindly invited to spend a sabbatical leave of absence at the Marine Life Research Group of Scripps Institution of Oceanography and the Coastal Fisheries Resources Division of South West Fisheries Science Center, NOAA in La Jolla, where a wide source of support was provided. Special thanks to Michael Mullin and John Hunter. I extend my acknowledgments to Henry Orr for his dedication and skilful illustrations. Idiomatic improvement and editing of the manuscript was graciously done by long time friends and colleages Roger Leong and Kristen Ray to whom I am greatly indebted, as well as to two anonymous referees.

\section{REFERENCES}

Alvariño, A. - 1965. Chaetognaths.- Oceanogr. Mar. Biol. Ann. Rev., 3: 115-194.

Alvariño, A., D.F. Verfaille and R.F. Ford. - 1983. Antarctic Chaetognatha. United States Antarctic Research Program Eltanin Cruises 10-23, 25 and 27. Biology of the Antarctic Seas. 14. Antarct. Res. Ser., 39 ( 2 ): 69-204.

Alvariño, A., J.M. Wojtan and M.R. Martinez. - 1990. Antarctic siphonophores from plankton samples of the United States Research Program. Eltanin cruises for spring, summer, fall and winter (Cruises 3-5, 8-23, 25-28, 30, 35 and 38). Biology of the Antarctic Seas 14. Antarct. Res. Ser., 49: 1-436.

Antezana, T. - 1976. Diversidad y equilibrio ecológico en comunidades pelágicas. In: F. Orrego (ed.), Preservación del Medio Ambiente Marino, pp. 40-54. Inst. Estudios Internac.Univ. Chile, Santiago.

Antezana, T. - 1978. Distribution of euphausiids in the Chile-Peru Current with particular reference to the endemic E. mucronata and the oxygen minima layer. $\mathrm{Ph}$. D. Thesis, Scripps Institution of Oceanography, Univ. California, San Diego. Diss. Abstr. Int., 9(8): 1-476.
Antezana, T. - 1981. Zoogeography of euphausiids of the South Eastern Pacific Ocean. In: Memorias del Seminario sobre Indicadores Biológicos del Plancton, pp. 5-23, UNESCO, Montevideo.

Antezana, T. - 1999. Hydrographic features of Magellan and Fuegian inland passages and adjacent Subantarctic waters. Sci. Mar., 63(Supl. 1): 23-34.

Antezana, T. and N. Aguirre. - 1976 . Nuevo límite septentrional para el krill antártico Euphausia superba Dana, en el Pacífico (Crustacea, Zooplancton). Ser. Cient. Inst. Antart. Chileno , 4 (1): 47-51.

Antezana, T. and M. Hamamé. - 1999. Short-term changes in the plankton of a highly homogeneous basin of the Strait of Magellan (Paso Ancho) during spring 1994. Sci. Mar., 63(Supl. 1): $59-67$

Antezana,T., L. Guglielmo and E. Ghirardelli. - 1992. Microbasins within the Strait of Magellan affecting zooplankton distribution. In: V. A. Gallardo, O. Ferretti and H. I. Moyano (eds.): Oceanografia en Antartica. ENEA Proyecto Antarctica - Italia, pp. 453-458. Ediciones Documentas, Santiago.

Antezana, T., M. Hamamé, Y. Eissler and S. Jara. - 1996. Traits of phyto- and zooplankton from the Strait of Magellan to Beagle Chanel on board Victor Hensen, leg 1 and 2,Oct-Nov 1994. Ber. Polarforsch., 190: 23-33

Artegiani, A. and E. Paschini.- 1991. Hydrological characteristics of the Straits of Magellan, Austral summer 1990/91 (FebruaryMarch 1991). Mem. Biol. Mar. Ocean., 19: 77-82.

Baker, A. de C. - 1959. Distribution and life history of Euphausia triacantha Holt and Tattersall. "Discovery" Rep., 29: 309-340.

Balech, E. - 1954. División zoogeográfica del litoral sudamericano, Rev. Biol. Mar. Valparaíso, 4 (1-3): 184-195.

Beers, J. - 1986. Organisms and the food web. In: R. W. Eppley (ed.): Plankton Dynamics of the Southern California Bight, pp. 84-97. Springer-Verlag, New York.

Briggs, J. C. - 1974. Marine Zoogeography. McGraw-Hill Book Co., London.

Brinton, E. - 1962. The distribution of Pacific euphausiids. Bull. Scripps Inst. Oceanogr., 8: 51-270.

Cabrini, M. and S. Fonda Umani. - 1991. Phytoplankton population in the Straits of Magellan. Mem. Biol. Mar. Ocean.., 19: 151-151.

Campodónico, I.G., L. Guzmán and G. Lembeye. - 1975. Una discoloración causada por el ciliado Mesodinium rubrum (Lohmann) en Ensenada Wilson, Magallanes. Ans. Inst. Pat. Ser. Cs. Nat., 6 (1-2): 225-239.

Carrada, G.C., M. Fabiano, P. Povero and V. Saggiomo. - 1994. Surface distribution of size-fractionated chlorophyll a and particulate organic matter in the Strait of Magellan. Polar Biol., 14 (7): 447-454.

Carrada, G.C., O. Mangoni, S. Sgrosso and S. Basualto. - 1996. Spatial distribution of size fractioned phytoplankton pigments along the Straits of Magellan and their daily variation in the Paso Ancho area (autumn 1995). In: F. M. Faranda, L. Guglielmo and P. Povero (eds.), 107-120. Nat. Progr. Ant. Res. Straits of Magellan, Ocean. Cruise, March-April 1995. Data Report. Lang-Art Grafique, Genova, Italia.

David, P.M. - 1958. The distribution of the Chaetognatha of the Southern Ocean. "Discovery" Rep., 29: 199-228.

Deacon, G.E.R. - 1937. The hydrology of the Southern Ocean. "Discovery" Rep., 15: 1-123.

Dearborn, J.H., F.D. Ferrari and K.C. Edwards. - 1986. Can pelagic aggregations cause benthic satiation? Feeding biology of the Antarctic brittle star Astrotoma agassizii (Echinodermata: Ophiuroidea). Biology of the Antarctic Seas. 17. Antarct. Res. Ser., 44: 1-28.

Días, P.C. - 1996. Sources and sinks in population biology. Trends Ecol. Evol., 11 (8): 326-330.

Ekman, S. - 1953. Zoogeography of the Sea. Sidgwick and Jackson, London.

Fonda Umani, S. and M. Monti. - 1991. Microzooplankton populations in the Strait of Magellan. Boll. Ocean. Teor. Appl., 9 (23) : $151-162$

Fuhrman, J. - 1992 Bacterioplankton roles in cycling of organic matter: the microbial food web. In: A. Woodhead (ed.), Primary Productivity and Biogeochemical Cycles in the Sea, pp. 361384. Plenum Press, London.

Genin, A., L. Haury and P. Greenblatt. - 1988. Interaction of migrating zooplankton with shallow topography: predation by rockfishes and intensification of patchiness. Deep-Sea Res., 35: 151-175. 
Ghirardelli, E., L.Guglielmo and G. Zagami. - 1991. Chaetognaths in the Strait of Magellan (a preliminary note). Mem. Biol. Mar. Ocean., 19: 167- 171.

González, H.E. - 1992. The distribution and abundance of krill faecal material and oval pellets in the Scotia and Weddell Seas (Antarctica) and their role in particle flux. Polar Biol., 12: 8191.

Gorny, M., W.E. Arntz and R. Soto. - 1996. Crustacea Decapoda: Report on the anomuran and brachyuran crabs. Ber. Polarforsch. 190: 60-63.

Guglielmo, L., T. Antezana, G. Constanzo and G. Zagami. - 1991. Zooplankton communities in the Straits of Magellan. Mem. Biol. Mar. Ocean. 19: 157 -161.

Gugliemo, L., T. Antezana, E. Ghirardelli , G. Zagami, A. Granata and G. Arena. - 1996. Zooplankton ecology in the Straits of Magellan (Paso Ancho) in early autumn 1995. In: F.M. Faranda, L. Guglielmo and P. Povero (eds.), pp. 233-250. Nat. Progr. Ant. Res. Straits of Magellan Ocean. Cruise, March-April 1995 Data Report. Lang-Art Grafique, Genova, Italia.

Gugliemo, L., T. Antezana, N. Crescenti and A. Granata. - 1997. Euphausiids. In: L. Guglielmo and A. Ianora (eds.), Atlas of Maríne Zooplankton / Strait of Magellan, pp. 87-97. Springer Verlag, Berlin.

Gutt, J. and T. Schickan. - 1996. Epibenthic communities analysed by underwater camera. Ber. Polarforsch., 90 (1996): 35-42

Guzmán, L., I.G. Campodónico, and J. Hermosilla. - 1975. Estudios sobre un florecimiento tóxico causado por Gonyaulax catenella en Magallanes. I.- Distribución espacial y temporal de $G$. catenella. Ans. Inst. Pat. Ser. Cs. Nat., 6 (1-2): 173-183.

Hamamé, M. and T. Antezana. - 1999. Chlorophyll and zooplankton in microbasins along the Strait of Magellan - Beagle Channel passage. Sci. Mar., 63(Supl. 1): 35-42.

Hamamé, M., T. Antezana and L. Guglielmo. - 1996. Diel changes in grazing rates of Euphausia vallentini in the Strait of Magellan (Paso Ancho) in early autumn 1995. In: F.M. Faranda , L. Guglielmo and P. Povero (eds.), pp. 259-268. Nat.Progr. Ant. Res. Straits of Magellan Ocean. Cruise, March-April 1995 Data Report. Lang-Art Grafique, Genova, Italia.

Hamner, W.M., P.P. Hamner, S.W. Strand and R.W. Gilmer. 1983. Behaviour of Antarctic krill Euphausia superba: chemoreception, feeding, schooling and molting. Science, 220: 433-435.

Hobson, E.S. and J.R. Chess. - 1986. Diel movements of resident and transient zooplankters above lagoon reefs at Enewatak Atoll, Marshall Islands. Pacific Sci., 40: 7-26.

Hopkins, C.C.E., P.E. Grotnes and J.E. Eliassen. - 1989. Organization of a fjord community at $70^{\circ}$ North: The pelagial food web in Balsfjord, Norway. Rapp. P.-v. Réun. Cons. int. Explor. Mer, 188: 146-153.

Huntley, M.E. and P.P. Niiler. - 1995. Physical control of population dynamics in the Southern Ocean. ICES J. mar. Sci., 52: 457-468.

Isaacs, J.D and R.A. Schwartzlose. - 1965. Migrant sound scatterers: interaction with the sea floor. Science, 150: 1810-1813.

Jumars, P.A. - 1993. Concepts in Biological Oceanography. Oxford Univ. Press, New York.

Kaartvedt, S. - 1993. Drifting and resident plankton. Bull. Mar. Sci., 53(1): 154-159.

Kawamura, A. - 1976. A note on the surface swarm of lobster-krill Munida gregaria (Crustacea, Decapoda, Galatheidae). Bull. Plankton Soc. Jpn ., 23 (1): 13-18.

Larson, R.J. - 1986. Pelagic Scyphomedusae (Scyphozoa: Coronatae and Semaestomeae) of the Southern Ocean. Biology of the Antarctic Seas. 16. Antarct. Res. Ser., 41(3): 59-165.

Lipizer, M and G. Catalano. - 1996. Nitrogen assimilation and new production in a spring bloom in the Strait of Magellan during the 2nd Italian-Chilean Cruise (March 1995). In: F.M. Faranda, L. Guglielmo and P. Povero (eds.), p. 77-82. Nat. Progr. Ant. Res. Straits of Magellan Ocean. Cruise, March-April 1995. Data Report. Lang-Art Grafique, Genova, Italia.

Mackintosh, N.A. - 1934. Distribution of the macroplankton in the Atlantic sector of the Antarctic. "Discovery" Rep., 9: 65-100.

Magazzù, G., V. Saggiomo and F. Decembri. - 1991. Primary production and biomass of pico-, nano- and microphytoplankton in the Straits of Magellan (February-March 1991). Mem. Biol. Mar. Ocean., 19: 127-130.

Magazzù, G., S. Panella and F. Decembrini.- 1996. Seasonal vari- ability of fractionated phytoplankton, biomass and primary production in the Straits of Magellan. J. Mar. Syst., (9): 249-267.

Marín, V. and T. Antezana.- 1985. Species composition and relative abundance of copepods in Chilean fjords. J. Plankton Res., 7 (6): 961-966

Marino, D., D. Sarno and A. Zingone. 1991.- Distribution of phytoplankton populations in the Straits of Magellan (FebruaryMarch 1991). Mem. Biol. Mar. Ocean. 19: 147-150.

Mauchline, J. and L.R. Fischer. - 1969. The Biology of Euphausiids. Academic Press, London.

Mazzocchi, M.G. and A. Ianora. - 1991. A faunistic study of the copepod assemblages in the Stait of Magellan. Boll. Ocean. Teor. Appl., 9 (2-3): 163 -177.

Mazzocchi, M.G., G. Zagami, A. Ianora, L. Guglielmo, N.Crescenti and J. Hure. - 1995. Copepods. In: L. Guglielmo and A. Ianora (eds), Atlas of Maríne Zooplankton / Straits of Magellan, pp. 1-279. Springer Verlag, Berlin.

McKelvie, D.S. - 1985. Discreteness of pelagial faunal regions. Mar. Biol., 88: 125-133.

Overnell, J., A. Edwards, B.E. Grantham, S.M. Harvey, K.J. Jones, J.W. Leftley and D.J. Smallman. - 1995. Sediment-water column coupling and the fate of the spring phytoplankton bloom in Loch Linnhe, a Scottish fjordic sea-loch. Sediment processes and sediment-water fluxes. Estuar. Coastal Shelf Sci., 41: 1-19.

Panella, S., A. Michelato, R. Perdicaro, G Magazzù, F. Decembrini and P. Scarazzato. - 1991. A preliminary contribution to understanding the hydrological characteristics of the Straits of Magellan: Austral Spring 1989. Boll. Ocean. Teor. Appl., 9 (2-3): 106-126.

Patarnello, T., I. Bargelloni, V. Varotto and B. Battaglia. - 1996. Krill evolution and the Antarctic ocean currents: Evidences of vicariant speciation as inferred by molecular data. Mar. Biol. (Berl), 126 (4): 603-608

Perissinotto, R. and C. Mcquaid. - 1990. Role of the sub-Antarctic shrimp Nauticaris marionis in coupling benthic and pelagial food-webs. Mar. Ecol. Prog. Ser., 64 (1-2): 81-87

Pickard, G.L. - 1971. Some physical oceanographic features of inlets of Chile. J. Fish. Res. Bd. Canada , 28: 1077-1106.

Pullian, H.R. - 1988. Sources, sinks and population regulation. Am. Nat., 132: 652-661.

Richard, J.M. and R.L. Haedrich. - 1991. A comparison of the macrozooplankton faunas in two Newfoundland fjords differing in physical oceanography. Sarsia, 76: 41-52.

Saggiomo, V., A. Goffart, G.C. Carrada and J.H. Hecq. - 1994 Spatial patterns of phytoplankton pigments and primary production in a semi-enclosed periantarctic ecosystem: The Strait of Magellan. J. Mar. Syst., 5 (2): 119-142.

Schilder, F.A. - 1956. Lehrbuch der Allgemeinen Zoogeographie. Gustav Fischer, Jena.

Simmard, Y., R. de Ladurantaye and J.C. Therriault. - 1986. Aggregations of euphausiids along a coastal shelf in an upwelling environment. Mar. Ecol. Prog. Ser., 32: 203-215.

Sinclair, M. - 1988. Marine Populations: An Essay on Population Regulation and Speciation. Books in Recruitment Fishery Oceanography, Washington Sea Grant Program, Seattle.

Starr, M., J.C. Therriault, G.Y. Conan, M. Comeau and G. Robichaud. - 1994. Larval release in a sub-euphotic zone invertebrate triggered by sinking phytoplankton particles. J. Plankton Res., 16 (9): 1137-1147.

Syvitski, J.P.M., Burrell, D.C. and J.M. Skei. - 1987. Fjords: Processes and Products. Springer- Verlag, London.

Tabeta, O. and S. Kanamaru. - 1970. On the post larva of Munida gregaria (Crustacea, Galatheidae) in Penas Bay, Chile, with reference to mass occurrence in 1969. Sci. Bull. Fac. Agr. Kyushu Univ., 24 (4): 227-230.

Uribe, J.C. - 1988. Antecedentes sobre un tercer brote de veneno paralizante de moluscos, en la región de Magallanes. Ans. Inst. Pat. Ser. Cs. Nat., 18: 97-101.

Uribe, J.C. - 1991. Net-phytoplankton distribution in the Strait of Magellan. Boll. Ocean. Teor. Appl., 9 (2-3): 145-150.

Wassmann, P., I. Andreassen, M. Reigstad and D. Slagstad. - 1996. Pelagic-benthic coupling in the nordic Seas: the role of episodic events. Mar. Ecol., 17 (1-3): 447-471.

Wiebe, P.H., E.M. Hulburt, E.J. Carpenter, A.E. Jahn, G.P. Knapp, S.H. Boyd, P.B. Ortner and J.L. Cox. - 1976. Gulf Stream cold core rings: large-scale interaction sites for open ocean plankton communities. Deep-Sea Res., 23: 685-710. 